\title{
Shipping to the Caribbean in the 1820s - 1840s: William Roche, Halifax Merchant
}

\section{Julian Gwyn}

Initialement, les marchands d'Halifax avaient peu d'options dans leurs négociations. Pour leurs exportations de produits de la pêche et du bois, ils ont importé le rhum de la Nouvelle-Angleterre, le sucre et la mélasse antillais. La guerre d'Indépendance américaine et les guerres avec la France jusqu'en 1815 ont restreint les importations américaines et ont accru les possibilités dans les Caraïbes. L'ère de l'émancipation des esclaves a créé beaucoup d'incertitude dans un marché en déclin. C'est dans ce monde d'après-guerre que William Roche (1800-1887) a établi ses activités en tant que propriétaire de navires et de marchand import-export. Son cas peut être étudié pour la période de 1820 à 1840 grâce à l'heureuse survie de ses papiers d'affaires.

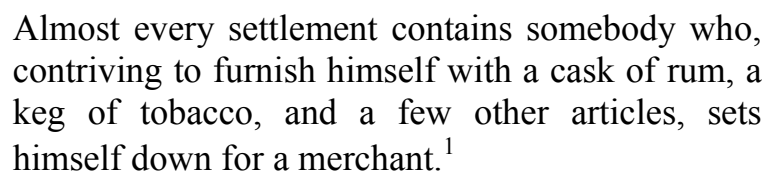

Much of Nova Scotia's early economy was dominated by a highly visible elite group of merchants. "What exactly did merchants do?"2 was the question asked some years ago by Jacob Price, the eminent historian of the colonial American economy. Price concluded that the successful merchant advanced credit and concentrated on the firm's balance sheet. Such balance sheets, in the absence of all but a little fixed capital, absorbed the attention of the commercial elite, wherever it was located. To supplement their capital, merchants especially bought medium-term bonds, when available, which paid higher yield than mortgages or land holdings. For short-term liquidity, they employed the bill of exchange, which dominated commercial transactions in the Atlantic economy in this era.

Their success in general was remarkable, as overseas trade greatly expanded before 1800. No sector of this trade grew faster than that with North America, which reached 30 per cent of all British overseas commerce by 1800 . Merchants in Halifax,

1 Colonial Patriot, 23 October 1831.

2 Jacob Price, "What Did Merchants Do? Reflections on British Overseas Trade, 1660-1790," Journal of Economic History 49 (1989), 278.

The Northern Mariner/le marin du nord, XXIII, No. 2, (April 2013), 99-122 
from the city's founding in 1749 , increasingly reflected this phenomenon. ${ }^{3}$ What follows will detail the experiences of one Halifax merchant house in an attempt to answer Jacob Price's question: What exactly did merchants do?

\section{William Roche}

Despite what is evident from the customs house and shipping records of the extensive trade between Nova Scotia and the West Indies, almost nothing survives to detail the activities of Nova Scotia merchants who carried on the business. The fortunate survival of the papers of William Roche (1800-87), the Halifax merchant, ship owner, and sea captain, enables us to put flesh and muscle on the otherwise dry bones of surviving official statistics annually compiled in Halifax and London.

Roche's letterbooks, logs, and accounts are, at times, most intimate documents which tell us much about the man. They include his rough notes and carefully detailed accounts, a range of letters relating to his business affairs, letters of introductions, and precise instructions to masters and supercargoes. There is a sketch of his vessel, the brig Ambassador, in full sail — too light to illustrate here - and a well-executed draft of the approaches to the port of Bahia, with its soundings. At Port of Spain, Trinidad, he recounted his tour with the architect of the neo-Gothic Catholic cathedral still under construction, noting its dimensions and the type of stone used. On the same voyage at St. Vincent he dealt with a drunken, mutinous mate, and provided a blow-by-blow account of the encounter. There also can be found his impressions of Hamburg when, on sailing from the Brazilian coast with a cargo of sugar, he was delayed there for repairs to his vessel.

In addition Roche listed the places he wished to visit before "returning from the sea." They included London, Naples, and "to go to the top of Vesuvius," to Sicily "in order to see Etna," to Rome, Venice, Gibraltar, Cadiz, Lisbon, Oporto, and the Azores. His hope was to "procure a cargo of fish at Newfoundland for Spain, or Portugal, and on the passage out stop at Fyal. If the cargo can be sold for cash at Fegueira, Oporto or Lisbon, proceed to Gibraltar, and there obtain freight for the Mediterranean, until all or as many of the places possible that are named here have been visited. On the return home visit Madeira, and if it be winter call at Tenerife, and run the trades down." ${ }^{4}$ It was a

3 Among the most useful studies are those by David A. Sutherland, "The Merchants of Halifax: A Commercial Class in Pursuit of Metropolitan Status" (PhD thesis, University of Toronto 1975); Eric W. Sager and Gerald E. Panting, Merchant Capital: The Shipping Industry in Atlantic Canada, 1820-1914 (Montreal: McGill-Queen's University Press, 1990); Allan B. Robertson, “John Wesley's Nova Scotia Business men: Halifax Methodist Merchants, 1815-1855" (PhD thesis, Queen's University, 1990); Julian Gwyn, Excessive Expectations. Maritime Commerce \& the Economic Development of Nova Scotia, 17401870. (Montreal: McGill-Queen's University Press, 1998); James D. Frost, Merchant Princes. Halifax's First Family of Finance, Ships and Steel. (Toronto: Lorimer, 2003).

4 Nova Scotia Archives (hereafter NSA), MG3/208. For an account of another merchant trading between Nova Scotia and the Caribbean, see Nancy Redmayne Ross, ed., The Diary of a Maritimer, 1816-1902: The Life and Times of Joseph Salter (St John's, NL: International Maritime Economic History Association, 1996). 
dream that he never realized.

Prominently placed in the front page of his invoice book and quite alone, where almost every other page is cluttered, is found a speech given by Shakespeare's Brutus:

There is a tide in the affairs of Men,

Which, taken at the flood, leads on to fortune;

Omitted, all the voyage of their life

Is bound in shallows and in miseries.

On such a full sea are we now afloat;

And we must take the current, when it serves;

Or lose our ventures. ${ }^{5}$

Elsewhere he recorded his concept, perhaps typical of his social class, of the ideal woman. ${ }^{6}$

Who was William Roche? His father, Charles Roche, came from Cork, Ireland and as a young ship's master had sailed to the East Indies on vessels owned by a London alderman. ${ }^{7}$ Eventually he sailed as well to the West Indies. The American War of Independence found him in New York City, then the headquarters of the British army. In 1783, with many thousands of others, he went as a Loyalist refugee to Shelburne. There he married Elizabeth, the daughter of William McNab, another New York Loyalist family. ${ }^{8}$

His son, William Roche, born in Shelburne in 1800, was the second of three children. To sea as an adolescent, as early as 1820 or 1821 he was master of a vessel, owned jointly with his father. By 1826 young William was partner with his elder brother, Charles (1798-1878), who was later MHA for Shelburne and who maintained a drygoods store on Granville Street in Halifax. ${ }^{9}$ The two brothers initially used to dock there at Thomson's wharf.

Before Roche retired from trade in 1860, he had long given up his dreams of travel, and had prospered in a modest way as a land-based merchant, and served for many years as president of the Union Marine Insurance Company of Halifax, in which he held

5 Julius Caesar, IV, iii, 217-23; NSA, MG3/205b.

6 The two closely written pages start: "Good sense alone is insufficient for the acquisement of grace. Unfortunately we see many ladies of the most excellent understanding, not only negatively without grace, but positively ungraceful. There are other requisites to grace of the most essential kind. An amiable temper and a habitual disposition to please are of the first consequence. The expression of all violent passions is destructive of grace. The expression of all feelings unpleasant to others is equally so. So is the expression of selfishness in all its forms..." NSA, MG3/208.

7 Biographical Sketches of Leading Citizens of the Province of Nova Scotia (Halifax, 1900), 23-24. He died aged 68 in Shelburne on 8 August 1830, and was buried there in the Anglican cemetery.

$8 \quad$ She died aged 71 in Shelburne in 1837, Acadian Recorder, 27 May 1837.

9 His sister was Elizabeth Ann (1802-76). 
fifteen original shares. ${ }^{10}$

In 1839 William married Susan Manning, ${ }^{11}$ with whom he had two sons and a daughter. He served two terms as a Halifax alderman in 1849-52 and in 1862-65, and for some years acted as town assessor. Deeply interested in politics, he supported as wide a trade reciprocity as possible with the United States, Europe, and the Caribbean. Like so many others in Nova Scotia, he was strongly opposed to the 1867 federation with the Canadas and New Brunswick. His younger son, Edward (1850-81), the only one to follow his father and grandfather to the sea, became a ship's captain. Their elder son, William II (1842-1925), who ran a coal business, was president of the Halifax Insurance Company. ${ }^{12}$ This celebrated son, a year before his father's death, was elected to the House of Assembly and later to Parliament. After his electoral defeat in 1908, he was appointed in 1910 to the Senate. When he died the papers called him both the "best known citizen" and the "Grand Old Man of Halifax." Thereafter the family passed into obscurity. ${ }^{13}$

\section{West Indies Trade}

Before delving into the pattern of William Roche's West Indies experience, we must first sketch the historical context. Rum, sugar, and molasses helped drive Nova Scotia's economy from the 1770 s to the 1830 s. Rum was the staple drink of the poor, as William Forsyth, a Halifax importer, noted in 1798: "People who keep grog shops are the principal purchasers of rum; and what will bear most water is more saleable; provided it has no bad taste. Fine flavour is not looked for, it being used only by the lower orders." 14 Likewise Moorsom's Letters from Nova Scotia remarked that the poor used molasses "in place of sugar. By others it is used as a drink, when diluted with water."15

For some decades this trade was important to Nova Scotia. On duties imposed on West Indies imports initially rested much of the provincial revenue. Yet the West Indies was of small consequence and direct trade was negligible. In 1772, for instance, of the

10 It was incorporated by an Act of the Nova Scotia House of Assembly in 1838, with capital of $£ 40,000$ in 800 shares. His shares cost him $£ 50$ each. He sold five of these in 1845 . For the firm's papers for 1838-1880 see NSA, MG3/213-224.

1122 November 1839, Acadian Recorder.

12 William Roche II married Rachel Clara Henry (1860-1918). His firm of coal merchants and steamship agents was located at Roche's Wharf, 165 Upper Water Street. When his own political career took him to Ottawa, his firm was managed by his brother-in-law, Charles Henry. He was MHA for Halifax County (1886-94), MP (1900-8), and Senator (1910-25). He had as well been director of the old Union Bank of Halifax, Chronicle, 22 October 1925. His only surviving son, William III (1894-1983), had removed to Bedford by 1943 and "devoted his life to music and played the organ in many local churches," Chronicle-Herald, 3 January 1984, 83.

13 There are many other details on the family monument in Camp Hill cemetery, location: DD No. 24.

14 To William Postlethwaite in Grenada, 12 January 1798, NSA, MG3/150, 463.

15 William Scarfe Moorsom, Letters from Nova Scotia: Comprising Sketches of a Young Country (London, 1830), 58. 
1,205 vessels from North American ports that sailed to the British islands in the Caribbean, only seven came from Halifax. ${ }^{16}$ Simeon Perkins, who carried on a small trade from Liverpool, was the most prominent of Nova Scotians then trading to the Caribbean. Sending cargoes of low grade dry cod and lumber and occasionally selling schooners there, he imported return cargoes of rum, sugar, molasses, and salt. ${ }^{17}$

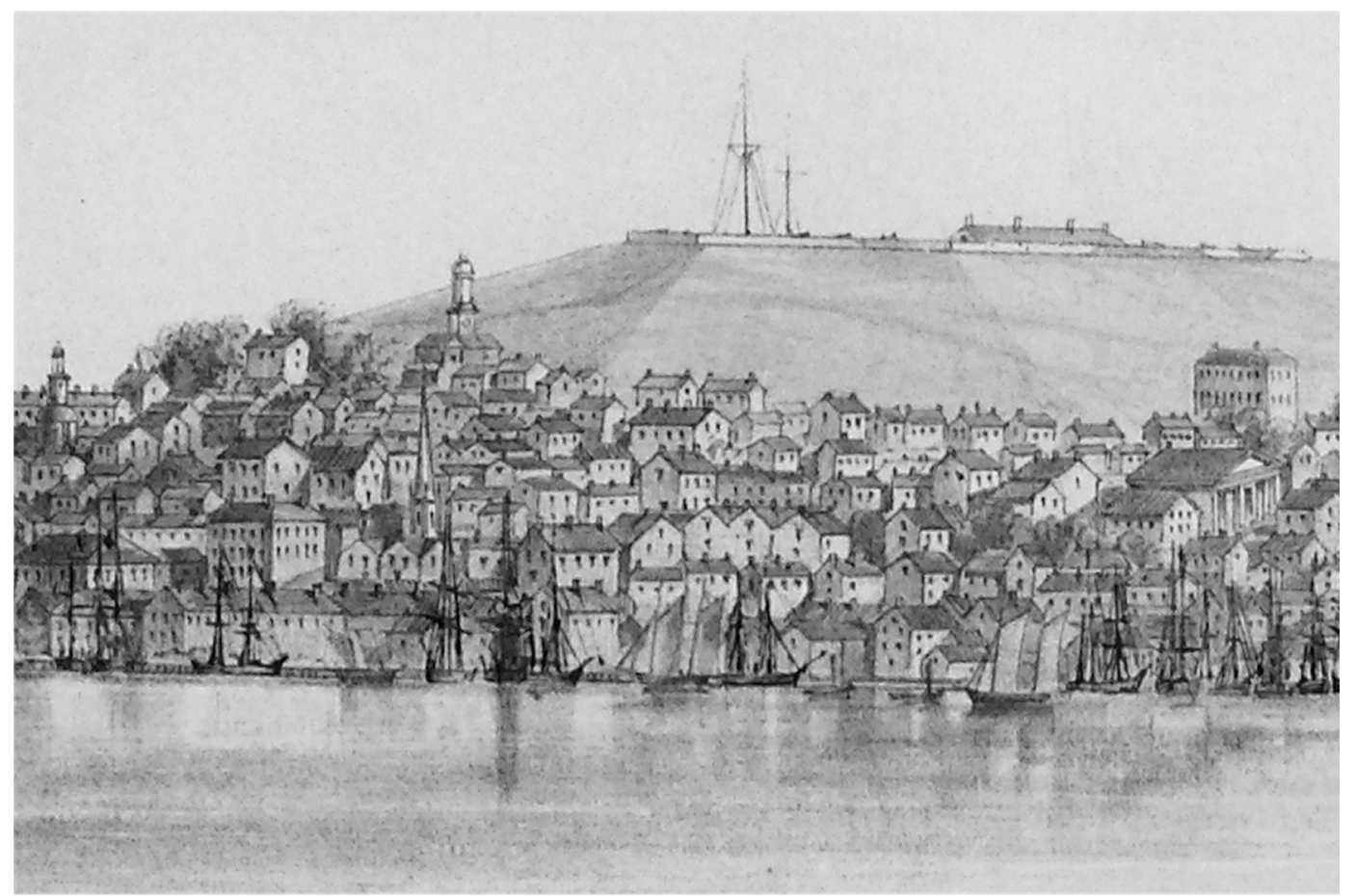

Illustration 1: Detail of lithograph of the Halifax waterfront in 1857, showing merchant wharves along Upper Water Street, the location of William Roche's establishment. Maritime Museum of the Atlantic M81.118.1, reproduced with permission.

Let us first consider what the statistics indicate. Most West Indies produce entered Nova Scotia until 1775 through New England. According to the customs ledgers, no more than 10 per cent of the rum imported into Nova Scotia between 1768 and 1772 came from direct trade with the Caribbean ${ }^{18}$ Only when war from 1776 to 1783 cut out New Englanders did Nova Scotia's trade expand. By 1778 some 2,440 tons or 15.6 per cent of the 15,400 tons of shipping that paid the Halifax lighthouse duty was bound for the West Indies. ${ }^{19}$

Despite the decade of peace from 1783 Nova Scotia's direct trade did not

16 The National Archives, Kew (hereafter TNA Kew), BT6/84 No. 41.

17 Perkins to Ebenezer Barker and Jabez Perkins, 2 June and 2 July 1765, NSA, MG1/752.

18 TNA Kew, CUST16/1.

19 Details derive from a database of vessels paying toll in support of the Nova Scotia Lighthouse. The list is deposited in the Julian Gwyn Fonds, Beaton Institute, Cape Breton University. Original returns are in NSA, RG31-105/1. 
experience a boom. Trade with the British islands from the United States did not vanish, as had unrealistically been anticipated by many. Nova Scotia's exports, though dwarfed by those coming from the United States, expanded principally by reflecting the expanded population resulting from arrival and settlement of loyalist refugees. Nova Scotia's share of the British West Indies market grew only slowly.

The outbreak of the British Empire's war with France in 1793 transformed the West Indies trade. As the islands were thrown open to American supplies, Nova Scotia's trade there stagnated. In 1790-91 vessels from the British West Indies entering the port of Halifax constituted 12 per cent of tonnage; by 1795-96 they had fallen to 8 per cent, recovering only in 1799-1801. As late as 1833 Henry Bliss, a keen and well-informed observer of imperial trade policy and Nova Scotia enthusiast, recalled: "These measures of government, in the year 1794, brought sudden distress and despair upon the North American colonies whose West India trade was thus rendered ruinous, fisheries worthless, and whose population so impoverished and disheartened, that many of the Loyalists, who had taken refuge there since 1783, and whose best hope of support depended on the West Indies trade, were now driven to abandon a dominion for which they had hitherto spared no sacrifice; and...many returned back to the United States, there to obtain, in the intercourse with British Islands, advantages denied to British colonies." 20

Nova Scotia's trade with the islands grew only from 1807 when the United States unilaterally imposed an embargo on its overseas trade. During the next decade the British North American colonies, led by Nova Scotia, acquired a larger, though still relatively small, niche in the West Indies market. By 1808-10 almost 29 per cent of all vessels paying toll in support of the Halifax lighthouse were inward bound from the West Indies. This amounted to 11,200 tons of shipping. By 1812-19 some 90 per cent of sugar products reached the province directly from the West Indies. Some of these imported sugar products were by then re-exported from Nova Scotia principally to other British North American colonies, as well as the U.S. ${ }^{21}$

Nova Scotia paid for its West Indies imports not only with such re-export earnings but also with exports principally of fish, wood products, and a variety of provisions. The war allowed Halifax to become the major supplier of naval stores to Jamaica, Antigua, Barbados, and Bermuda. Twenty-four such shipments of pitch and tar, spars, planks, timber, oars and rafters, as well as train oil, were sent expressly for the use of the Royal Navy in 1809 alone. $^{22}$ By 1812-19 95.5 per cent of Nova Scotia's vessels, carrying fish, found markets in North American or West Indies ports.

The 1830s witnessed a significant shift for Nova Scotia in the patterns of Caribbean trade. The changes had much to do with the ending, between 1834 and 1838, of slavery in the British Empire and the subsequent labour dislocation. Plantation owners discovered that, where there was a choice, free Black labour would always select

20 The Colonial System (London, 1833), 17.

21 Data come from a microfilm edition by Julian Gwyn, Nova Scotia Naval Office Shipping Lists, 1730-1820 (Wakefield, Yorkshire: British Association for American Studies, 1982).

22 TNA Kew, ADM106/2028. 
occupations less onerous than cutting sugar cane, picking cotton, or harvesting tobacco, if the wages were inadequate. After 1838 many former slaves chose to avoid the disheartening working conditions associated with sugar and turned instead to earning a subsistence living from cultivating small garden plots, raising poultry, swine, and goats or opening small shops. ${ }^{23}$ This led to a catastrophic decline in sugar production.

The story is significant for the West Indies and their trading partners. On St. Vincent, Grenada, and Tobago, sugar production never again reached pre-emancipation levels. It was 1934 before Jamaica reached its pre-abolition level of sugar production, Guiana not until 1861, St. Lucia not until 1858, Montserrat only between 1866 and 1896, Nevis only between 1871 and 1882, Dominica only between 1842 and 1889 and St. Kitts in 1839. Taken together, the British Caribbean's average level of production in 1830-39 was regained only in 1860-69, when its share of world output had fallen from 40 per cent to only 10 per cent. ${ }^{24}$

Tariff reform undertaken by the Imperial Parliament permitted Nova Scotia's merchants, from the late 1830s on, to exploit the trade possibilities thrown open to them in the French and Spanish sugar islands and the Brazilian coastal ports. ${ }^{25}$ Such was the rising demand in Europe and America, especially for sugar from West Indies markets, that by the early 1840s Cuba alone exported more sugar than all the British West Indies colonies together.

The shift by Nova Scotian importers was as sudden as it was dramatic. William Roche of Halifax noted this in 1837: "There appears to be a general inclination by people engaged in commerce here to expand their trade and to ship part of our exports to the foreign islands." Two years later, a customs official noted: "within the last eighteen months nearly all the importations of West India produce have been from the Foreign Islands. ${ }^{26}$ Evidence for this tendency was reflected in trade statistics collected by the Customs House in London. In 1832-36 the average annual value of British North American (the bulk from Nova Scotia ports) exports to the British Caribbean was $£ 268,000$, but by $1849-53$ it had fallen by almost 90 per cent to $£ 25,000$.

Until the 1830s the British islands supplied Nova Scotia with about 90 per cent of its sugar imports. Much of the rest came from the foreign islands. Yet from 1837 on, the British West Indies supplied only 3.5 per cent of Nova Scotia's sugar imports, while almost 94 per cent came from the Foreign Islands.

23 Julian Gwyn, "The Economics of the Transatlantic Slave Trade: Review Essay," Histoire sociale-Social History, 25 (1992), 151-62.

24 J.R. Ward, Poverty and Progress in the Caribbean (London: Methuen, 1985), 27.

25 Nova Scotians were well familiar with such foreign supplies, for in wartime captured French prize vessels, carrying such goods, were occasionally condemned by the Halifax Vice Admiralty court. William Forsyth noted in January 1798: "There is a large quantity of prize Havana sugar here, which will keep down the price," letter to William \& Samuel Fairbrace, in Barbados, 13 January 1798, NSA, MG3/150.

26 W.W. Isles [warehouse keeper] to T.N. Jeffery, Halifax, 15 April 1839, TNA Kew, CUST34/665, fol. 87. Jeffery died 21 October 1847 after forty-five years in the customs service, TNA Kew, CUST34/673, fol. 247, and obituary Times, 30 October 1847. 


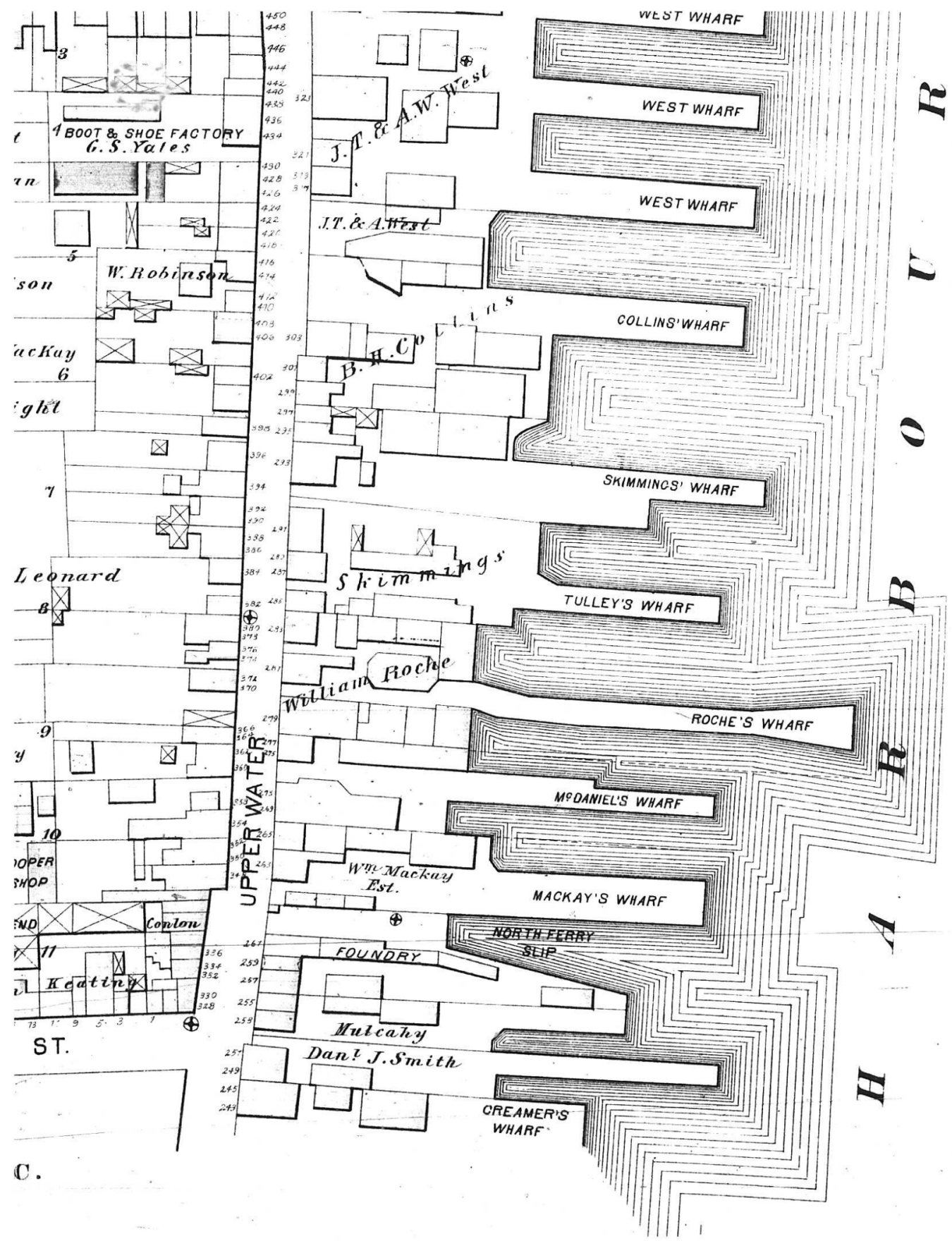

Illustration 2: Detail from W.H. Hopkins, City Atlas of Halifax, N.S. (1878), plate D, showing William Roche's establishment on Upper Water Street. Courtesy of the Nova Scotia Archives. 
Imports of molasses demonstrate an equally impressive shift away from the British West Indies. The British islands, from supplying about 95 per cent of Nova Scotia's needs between 1832 and 1837, thereafter, until at least 1853, supplied hardly more than 14 per cent. The bulk of the rest came from the foreign West Indies. In an expanding market, the British colonial sources of molasses fell by more than 80 per cent. With the evidence both of sugar and of molasses, it was clear that the British West Indies were no longer price competitive. By concentrating on the foreign sources for their imports and increasingly their exports, British and Irish merchants as well as those from Nova Scotia thus enabled slave-based production to continue for a generation after Parliament had closed it for the Empire.

If British North American imports from the British West Indies collapsed in the 1830 s, exports to the islands faltered as well, and then drifted downwards. When compared to the $1830 \mathrm{~s}$, for instance, the value of such exports had fallen in the early 1850 s by 40 per cent. The volume was in fact maintained, but the commodity prices collapsed in the depression that swept much of the Atlantic world for several years in the 1840 s and early 1850s. By the 1840s when direct trade between the United States and the British islands had been re-established for a decade, Nova Scotia for the first time since the 1780s ceased to be a significant re-exporter of American provisions - especially flour — to the Caribbean market.

As prices fetched for Nova Scotia's exports in the Caribbean collapsed in the 1840s, Nova Scotia fishermen and those who supplied wood products received less from the export merchants, based principally in Halifax. So long as merchants bought low in North America, they could still survive at low price levels in the West Indies. As an example, the wholesale price of Jamaica rum and molasses in the early 1830s was half that of the wartime years 1813-14, and sugar one-quarter. Both sugar and rum prices recovered somewhat in the late 1830s, only to collapse in the depression of the 1840s to historically low levels. Such was the stressful background in which William Roche hoped to make his fortune.

\section{Trading Voyages}

In William Roche's time at sea in command of his own vessels, he undertook voyages to Quebec, Antigua, Barbados, Berbice, Bahia, Pernambuco, St. Vincent, St. Thomas, Trinidad and Tobago, Hamburg, and London. Seventeen such trading voyages are recorded, all but one of them between 1828 and $1835 .{ }^{27}$ Some of the details follow. In March 1828 he sailed his brig Ambassador to Pernambuco, with a cargo owned by James and Michael Tobin $^{28}$ equally with Mather Byles Almon. ${ }^{29}$ He carried letters of

27 Details are found either in his letterbook or business records, NSA, MG3/205a, 205b and 207.

28 Terry M. Punch, “James Tobin, 1774-1838," Dictionary of Canadian Biography (Toronto: University of Toronto Press), 7:867-8 (hereafter $D C B$ ).

29 Almon asked Messrs LeBreton and Company (22 March and 28 April 1828) to extend to Roche credit of 400 milraes, as part payment of his freight earnings on a cargo split equally between James and Michael Tobin and Almon himself. Almon was agent for the Halifax 
introduction from William J. Starr ${ }^{30}$ and Almon. At Bahia "in search of a better market," at the end of May, he collected a cargo of sugar consigned to Hamburg, which brought him to Europe for the first time. ${ }^{31}$ Six months later he was again bound for the West Indies, freighting cargo owned by the Tobins. ${ }^{32}$

His third recorded voyage to the West Indies occurred three months later, in February 1829, when he was again carrying freight for the Tobins to Antigua. ${ }^{33}$ His return cargo of 6,356 gallons of molasses and 10,355 lbs. of sugar, valued at $\$ 1,657,{ }^{34}$ was consigned to Quebec, a port new to him. ${ }^{35}$ In May he sailed from Halifax for Carlisle Bay, Barbados. As he could not obtain the minimum prices necessary for profit for his cargo, he weighed anchor for Scarborough, Tobago's principal town and Port-of-Spain, Trinidad. In July 1829, again as master of the brig Ambassador, he was bound for Barbados with a cargo of fish and wood products owned by Enos Collins ${ }^{36}$ and John A Richardson. Collins wrote to him as he cleared Halifax: "As you are well acquainted with the markets generally in the West Indies, we shall leave it entirely to yourself to proceed to such ports as you may think best calculated to afford us a profitable return on our shipment." 37 As Barbados proved unpromising, the cargo was sold in Berbice.

His activities for almost the next eighteen months are unclear, though he sailed to Barbados in May 1830 and called at Tobago and Trinidad. If he was as active then as he was in 1831, he would have fitted in at least three further voyages to the West Indies in the interval. In 1831 and 1832 he sailed on six more voyages to the Caribbean as master

Marine Insurance Association, which he helped establish in 1838 and was co-founder of the Bank of Nova Scotia. He failed to realize that his cashier, James Forman, beginning in 1844, had embezzled $\$ 315,000$ from the bank. He was reluctant to invest much in Nova Scotia, from which the Bank of Nova Scotia also absented itself, Kenneth Pryke, "Mather Byles Almon, 1796-1871," DCB (Toronto: University of Toronto Press, 1972), 10:6-8.

30 Starr called him "a particular friend of mine" and noted that though Roche was carrying freight he was looking for an "adventure at his own risk on the homeward voyage," to John Mathers, Esq., 21 March 1828, NSA, MG3/205a.

31 Letters of introduction, Robert Pelly at Pernambuco to J. Vanzeller and George Nainbmaster, both of Hamburg, 31 May 1828, noted that "this is the first time he visits your place," ibid.

32 J. and M. Tobin to John L. Wainwright, 29 November, 1828, ibid.

33 J. and M. Tobin to B.L. Trimmingham, Esq., 22 February 1829 and noted "Capt. Roche is a friend of ours," ibid.

34 Darrell to Charles and William Roche, Antigua, 25 April 1829, ibid.

35 He was described as "of the house of Charles and William Roche, Halifax. He goes to Quebec...with a cargo of produce," Darrell and Co. to Twicker and Stewart, merchants at Quebec, Antigua, 25 April 1829, ibid.

36 Collins was master in his father's vessels, while still a minor. His own vessels earned large profits in the French wars, both by trade and as privateers. Possessed of a large capital by 1815, he invested heavily in US bonds, banks, and other securities and in 1822 planned to move to the United States. Instead he married and built a mansion in the southern suburbs of Halifax. He helped found the Halifax Banking Company. Diane Barker and David A. Sutherland, "Enos Collins, 1774-1871," DCB, 10: 188-90.

37 Collins to Roche, 18 July 1829, NSA, MG3/205a. 
of the schooner William. In January 1831 he loaded a cargo in Shelburne for Barbados and looked for a return cargo in St. Vincent. His next voyage in May took him first to Pernambuco and thence to Bahia, where he carried a letter of introduction from Jonathan Prescott, who described Roche as "the son of an old and respectable friend of mine in Shelburne and has a claim on my regard." ${ }^{38}$ Unable to find the return cargo he desired, he sailed for St. Thomas. In September, again in the Caribbean, he reached Barbados just after the island had been devastated by a hurricane, noting in his log: "Scene of desolation here is truly awful. Every house more or less injured. Greater part entirely destroyed. Many of the inhabitants killed or wounded. The sick and wounded carried to the ruins of the churches. ${ }^{, 39} \mathrm{He}$ sold his cargo in Tobago and loaded a return cargo, also putting into Barbados.

The 1830 s proved a particularly difficult time for trade. The spreading temperance movement in Nova Scotia led to a gradual collapse in rum consumption, while in Upper and Lower Canada the whiskey business further reduced the demand there for West Indies rum. This changing environment obliged Roche to alter his usual trading pattern. To obtain less expensive cod than was available in the Halifax wholesale market and to avoid a wholesale market glutted with West Indies produce, for the first time he sailed with a mixed cargo for St. John's, loaded fish before returning to Halifax to complete his cargo with wood products before proceeding to the West Indies. ${ }^{40}$ To reduce his risks and open himself to new capital, he formed, in 1833, a partnership with T.C. Kinnear. The strategy worked until Kinnear settled in Demerara in 1837, after which Roche carried on alone. ${ }^{41}$

While the partnership survived it allowed Roche by 1835 to become, however briefly, a land-based merchant. Now he had to provide detailed instructions to a succession of ships' masters and supercargoes to ensure that they sought the best information, remained alert to changing market pressures and promptly carried out their orders. To masters he offered bonuses occasionally for return voyages completed within two-and-a-half months. The supercargoes were usually young sons of the merchant community of Halifax who were learning the trade under his tutelage. In one case he actually shared the risk of the speculation for two cargoes with one of these young men.

Roche's instructions to both masters and supercargoes tell us much about the mechanics of the business. In 1834, by way of example, he told John Pengilly, as master of the newly acquired Augusta, to effect a sale of the ship's cargo in Barbados. If he could not get a return cargo, he should load ballast and return to Halifax without delay, taking whatever freight and passengers available. If he had to delay in any port for as much as a dozen days, he was ordered to put the vessel ashore and have her cleaned. At the same

38 Acadian Recorder, 5 Aug 1826. Prescott was brother to the celebrated Cornwallis Township horticulturist, Charles Ramage Prescott.

39 NSA, MG3/205.

40 This first cargo, valued at H£410, was shipped on Roche’s Persa, John Pengilly, master, in September 1833, NSA, MG3/205a.

41 The partnership was dissolved on 1 April 1837. See Roche's letter of 26 April 1837, NSA, MG3/207. 
time he instructed Henry Creighton, the supercargo, telling him that he had informed Messrs Hill \& Musson, his agents in Barbados, of his hope to get $\$ 3.25$ per quintal for the cod on board, "which is the only article we limit." ${ }^{42}$ Proceeds from the sale should be in bills of exchange on London, if they could be had, at the exchange rate of $\mathrm{H} £ 500$ for $£ 100$ sterling. The latest quotations from Barbados available in Halifax were only between $\mathrm{H} £ 470$ and $\mathrm{H} £ 480$. "We have little doubt as the crop comes in, they will go lower. The lower you obtain them, the more advantageous it will be. We do not think private bills will answer at all from the West Indies unless they should be endorsed by the most respectable merchants there. If bills cannot be had, you will bring doubloons with you." If the report in Barbados of markets either on the Spanish Main or elsewhere in the West Indies was poor, Creighton should accept \$3.00. If that was impossible, then he was to consult with Hill and Musson to decide where the cargo should be sold. If he proceeded to Demerara, Roche recommended "the greatest caution in your transactions there, and to endeavour to sell for immediate payment...or even part cash part produce...preferring rum altogether...Secure from $\$ 400$ to $\$ 500$ cash, which is usually allowed in agreement for disbursements of the vessel."

If the Demerara news was unpromising, Creighton could touch at Tobago, St. Vincent, or Grenada, but not Trinidad. "If you should sell at Tobago, your proceeds will be rum, cash if you can get it; at St Vincent, rum and molasses; at Grenada, rum. If there is no prospect of making a sale at the Main or any of the Windward Islands, we would wish (rather than sacrifice the cargo) for you to proceed to Kingston, Jamaica. On your arrival there call upon McDonal, Watt \& Cramsie to dispose of the cargo for you." Creighton was further instructed to bring "your produce from there in doubloons, and try to obtain any freight that might offer for this place without causing you detention...as the charges at Jamaica are usually very heavy."

Roche then wrote to his agents in Barbados. He assured them that the cargo of ninety-nine hogsheads of Labrador, bay, and shore cod "will be found of excellent quality, having been put up here in the best order. The beef and the pork is the best Canada inspection, which we have been induced to ship, trusting that under the present order existing with you for levying the duty on foreign beef \& pork this will meet with ready sale at a remunerating price. ${ }^{\circ 3}$ Despite all the precautions, the cargo sold poorly; by the time Augusta reached Halifax, Roche and Kinnear owed their agents in Barbados some $\$ 385$. The news of the depressed state of the West Indies market for northern produce had reached Halifax earlier, so the only unanswered question was the size of their anticipated loss.

The situation was equally dismal for West Indies produce in Halifax, as he told Hill and Musson, "All articles of WI produce are very low at present, and not much probability of an increase in prices, as the Quebec market offers very little encouragement ${ }^{\prime 44}$ for shipments when the St. Lawrence again became navigable. That

42 Roche to Creighton, 5 February 1834, ibid.

43 Roche to Hill and Musson, 5 February 1834, ibid.

44 Roche and Kinnear to Hill and Musson, 27 March 1834, ibid. 
they saw Quebec as crucial to their operations is of great interest. A year later Roche was encouraging his master and supercargo to return "before the closing of Quebec navigation," as this would have "considerable influence" on the price given in Halifax. Roche returned to the subject again in October 1836, when he wrote to his Barbados agents: "Advices from Quebec are not very encouraging for rum, the large quantity of whisky tending to reduce the consumption of rum very much." ${ }^{, 4}$ Again, in April 1840, he wrote that "sanguine hopes are entertained that this year there will be large quantities of sugar required in Canada." ${ }^{" 46}$ Roche never wrote of any other port in the British North American market in such terms.

To begin to recoup the loss Roche himself sailed on three of the next four voyages. In May 1834 the partners dispatched the brigantine Augusta to Demerara, with Roche as supercargo. The cargo this time included fifty-one hogsheads of cod and nine barrels of prime beef, with the usual assortment of staves, hoops, shingles, and pine lumber. A second voyage to Demerara was made in August, with H.R. Marshall, an experienced supercargo. The cargo was valued at $\mathrm{H} £ 523$ and carried twenty-five barrels of Virginia and fifteen barrels of Genesee Valley flour, "both superior articles," as well as cod, haddock, mackerel, and 393 gallons of whale oil. If neither Demerara nor Berbice offered a sale, Roche told Marshall, "at a saving price...run to Barbados and contact Messrs. McCan and Company for market information on the surrounding. If they too are discouraging, then proceed to Kingston. ${ }^{, 47}$ If the cargo sold at Demerara, he was to take rum in payment. He was to accept molasses only if he needed it for ballast. If the cargo sold at Barbados, the partners wanted government bills at about $\mathrm{H} £ 480$ per $£ 100$, "if not, then doubloons \& dollars at par." If produce was available there, then Marshall could load rum and good sugar. Like other supercargoes he was told to send the parties information via New York or Boston.

In October 1834 Roche returned to sea as master of the brigantine Persa, a possible indication that the business was suffering. He made for Barbados with a cargo worth H£580. The vessel brought a return cargo from St. Vincent, where he had reason to believe he was cheated. Roche complained to his supplier there of "an unusual loss of gauge of both rum and molasses, which we think right to mention to you, as the casks appear to be all in good order and not to be caused by leakage." 48

In January 1835 Augusta sailed with a new cargo worth $\mathrm{H} 4866$ to Barbados, where the master was to contact Cavan \& Company, who were assured that the dry cod was Labrador, "put up in the best order," while the beef was Nova Scotian, "which is equal in quality to any shipped from the US." a cargo he was to get cash, rum, or "good bright molasses," both cheaply, as the Halifax

45 Roche and Kinnear to Hill and Musson, 22 October 1836, ibid.

46 Roche to Faulkner and Wheeler, of Saint John, 16 April 1840, ibid.

47 Kinnear (Roche was absent in Shelburne) to Marshall, Halifax, 10 August 1834, ibid.

48 Roche and Kinnear to William Durham, 1 January 1835, ibid.

49 Roche K. Kinnear to Cavan and Company, of Barbados, 1 January 1835. They introduced themselves by enclosing a letter of introduction from a Mr. Torrence, "who was in Halifax recently." They hoped to enlist them as their correspondents. Ibid. 
market was expected to remain dull. This cargo also proved a serious disappointment for it fetched only $\$ 218$ as the Barbados market was glutted with "our exports," and so Roche determined not to "venture any shipments until a rise in prices" $" 50$ occurred.

In June 1835 the partners bought Betsy, a Liverpool schooner, and hired John Campbell to fish on the Labrador coast. Accompanied by Augusta she returned with 256 quintals, which Roche described as "certainly the worst we have seen this year, which is no doubt owing to the bad weather." They sold the schooner to Campbell for £210: half cash, half bills of exchange at three months' sight. "We trust that Betsy will be more successful with you than with us. She is certainly a very cheap vessel and we would not have disposed of her at that price had we any way of employing her in the winter. We send her to you with the articles she had on board when purchased." ${ }^{51}$

This was the first of twenty-six more voyages in eight-and-a-half years between June 1835 and January 1844 for which records survive. Each cargo cleared Halifax with a mixture of hope for profit and calculation based on a great range of intelligence that reached Halifax.

Here it should be observed that there was at least one serious drawback to doing business based in Halifax. For a place of some commercial importance, the town was not served well by the local newspapers. There was no adequate monthly, weekly, and daily information on the state of trade, shipping intelligence, exchange rates, stock prices, and wholesale and retail prices, or a review of the markets. Such newspapers were found in Kingston (Jamaica), Boston, New York, Baltimore, New Orleans, Liverpool, London, San Juan (Puerto Rico), Pernambuco, Bahia and other places of equal commercial importance. Even for something as important to Halifax merchants as wood products, for instance, there were no regular price quotations in any newspapers either in Nova Scotia or New Brunswick. Halifax merchants seemed satisfied to be privately informed on prices in their export markets around the Atlantic world. Since they dominated the import carrying trade, whether from Europe, the United States or the Caribbean, they apparently saw no need for publicly printed commercial information.

The first of these shipments, in mid-June 1835, went by Persa, with Roche again as master. It was worth $£ 938$ and again it brought "very heavy losses." ${ }^{52}$ Part of the cargo of unsold fish was returned to Halifax and was promptly sent off to Newfoundland where it was sold. ${ }^{53}$ Undeterred, in September the partners sent yet another cargo in Persa, this time to Berbice. Only if "rum was high," and sugar could be bought cheaply, would they take the proceeds of their sales from it. ${ }^{54}$ Another cargo, worth $£ 530$, went out in October 1835 in Augusta, bound for Demerara. The supercargo, James Ritchie, was to take proceeds in "good light sugar," or molasses "of good quality." He was to dispose of the

50 Roche and Kinnear to Messrs Cavan, Halifax, 14 March 1835, ibid.

51 Roche and Kinnear to John Campbell, 5 November 1835, ibid.

52 Roche and Kinnear to Cavan \& Company, 27 July 1835, ibid.

53 Roche and Kinnear to Baine Johnston at St. John's, 20 October 1835, ibid.

54 Roche and Kinnear to Edward Goudge, 17 September 1835, ibid. 
cargo both by wholesale or retail. ${ }^{55}$ Yet another cargo worth $£ 402$ went via Persa to Demerara in January 1836, with T.C. Kinnear as supercargo. This heralded the end of the partnership with Kinnear. In February 1836 Augusta was sent to Kinnear at Demerara, with a cargo worth $£ 478$. In March 1836 Persa was sent to Demerara, again consigned to T.C. Kinnear, with a cargo worth $£ 650$ of Labrador cod, boards and staves. None of this activity proved very profitable.

With business not turning out as hoped, Roche decided to try to outflank the Halifax wholesale market, where he believed fish was overpriced, and buy directly in St. John's. It was a strategy he later applied to wood products. By buying directly in New Brunswick, where he favoured St. Andrews, or in Newfoundland, he hoped to avoid the Halifax wholesale wood market. This approach had the perceived additional benefit of disposing of at least a portion of his West Indies return cargoes, not on the now habitually glutted Halifax market, but in such important regional ports.

The new policy, as it related to fish, began with a letter in May 1836, and an admission that there had been little profit from "our shipment to Demerara. "If it is possible the ensuing season," he told Baine Johnston in St. John's, "to procure shore fish at a price at all reasonable, to purchase them and leave the Labrador to those who are more fortunate in shipping them." with the few West Indies goods received in part payment from the sales in Demerara. They achieved this not in Halifax, but by sending Augusta to St. John's, earning a small profit by shipping molasses and sugar.

Augusta now collected a cargo of fish and, after loading additional commodities in Halifax, sailed for Demerara. It was something of a fiasco as Augusta had "fallen to the leeward of Barbados and being unable to get up, the master had placed the cargo in the hands of an agent "who...made a wretched business of it." Persa in October 1836 followed the same track, first making for St. John's to load a cargo of fish, carrying Puerto Rican sugar and rum for sale there. The net returns, along with $\$ 4,000$ sent there by Roche, were used to purchase "dry fish in bulk"-1,300 quintals of "best mercantile shore codfish" bought in St. John's 1,000 quarts of Madeira, payment for which would be a shipment of West Indies goods in the spring of 1837. Persa sailed with her cargo in mid-December 1836 for Barbados. Hill and Musson were assured that the Madeira was "of excellent quality" and the flour was extra superfine Hamburg, while the boards were "better than are generally shipped" from Halifax. ${ }^{58}$ The proceeds were to be in "undoubted bills of exchange." If a loss was anticipated, then the cargo was to be sent to Demerara.

The new policy as it related to lumber was initiated in 1838. The first such order was issued in July 1838 when Roche sent to St. Andrews a cargo worth £423, instructing

55 Roche and Kinnear to James J. Ritchie, 31 October 1835, ibid.

56 Roche and Kinnear to Baine Johnston at St. John's, 25 May 1836, ibid.

57 Roche and Kinnear to Baine Johnston at St. John's, 16 October 1836, ibid.

58 Roche and Kinnear to Hill and Musson, 14 December 1836. A day earlier they had written to Demerara, asking that if the cargo sold there, they were to secure "good molasses," to Winter and Preston, 13 December 1836, ibid. 
the ship's master to buy "large pine boards of good quality." 59 Many similar orders involving several small coasters soon followed. This perhaps otherwise sound scheme faltered for two principal reasons. Roche found that the Halifax market was usually "abundantly supplied by our coasters" $" 60$ in view of the declining West Indies demand for wood products. Of more importance, he found it very difficult to get paid for the goods shipped and sold there. By November he complained to the two merchants with whom he was dealing, George McCulloch and James Boyd, who owed him money, that "the mode of conducting bank business at St. Andrews affords so little accommodation to merchants" and that he was left quite unsure "upon what principle they expect to make money without transacting business."61 Boyd wanted to ship him lumber for consignment, while Roche wanted bills of exchange drawn on a Liverpool or London merchant, as they had originally agreed, warning his debtor that "a British merchant is free to conduct his business in the manner more agreeable to himself, provided he injures no others." ${ }^{62}$ His experiment in the Bay of Fundy was not repeated.

By the spring of 1837 Roche wanted to position himself better to export to the "foreign islands." This market, which he had never tapped, was then widely viewed in Halifax by those "engaged in commerce" as an excellent outlet for "a part of our

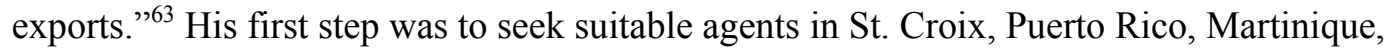
and Guadeloupe. Despite the recent record of losses, he seemed expansionist. At the same time he sought new correspondents in St Vincent, Grenada, Antigua, St. Kitts, and St. Thomas.

The decline in consumption of fish by the freed Blacks in the British islands was at the root of Roche's problems. "If the labourers," he commented in May 1838, "perform the work which is required on the estates, the consumption of provisions (more particularly codfish) will increase, and again afford us a profitable carrying trade, without the necessity of exporting such large quantities of specie as has been done of late. The want of the article is now being felt both here and at N. Brunswick, the Banks in consequence curtailing their discounts, endeavouring at the same time to get specie in to replace that which has been drawn from them for the W. India trade." ${ }^{4}$

This was a classic statement of the disillusioned abolitionist. Such men had ignored the plantation owners' economic experience. Abolitionists had hoped to see emerge a sober, industrious labour force, prosperous from its own efforts. The inculcation of British working and consumer habits would lead, they imagined, to increased prosperity. With the end of slavery they had expected the labour supply to expand along

59 Roche to Muirhead, July 1838, ibid. Later he sent some rum and herrings to Crane and McGrath at Saint John, 31 October 1838, and noted "I believe the skipper is not a very smart fellow, but being a Barrington man, then he will find his way round to you safely," ibid. Roche to George McCulloch of St. Andrews, 18 August 1838, ibid.

61 Roche to James Boyd of St. Andrews, November 1838, ibid.

62 Roche to Boyd, 27 February 1839. Roche to McCulloch, 27 February 1839, ibid.

6326 April 1837, ibid.

64 Roche to James Fergus at St. John's, 3 May 1839, ibid. 
with a rise in labour productivity and enlarged exports.

When the freed Blacks chose instead to abandon the sugar fields and cane crushing mills, Roche, like many in Nova Scotia, was left deeply worried. As a direct consequence, his expansion plans never matured and he remained largely aloof from the rapidly expanding sugar markets of Cuba and Puerto Rico. He confined himself to an inquiry about the prospects for lumber and fish and the price of Martinique and Guadeloupe molasses. Misreading the capacity of Spanish slave plantations to expand production, he wrongly believed that "Puerto Rico will scarcely produce sufficient sugar and molasses to supply all the adventures that will visit there for the next crop." 65

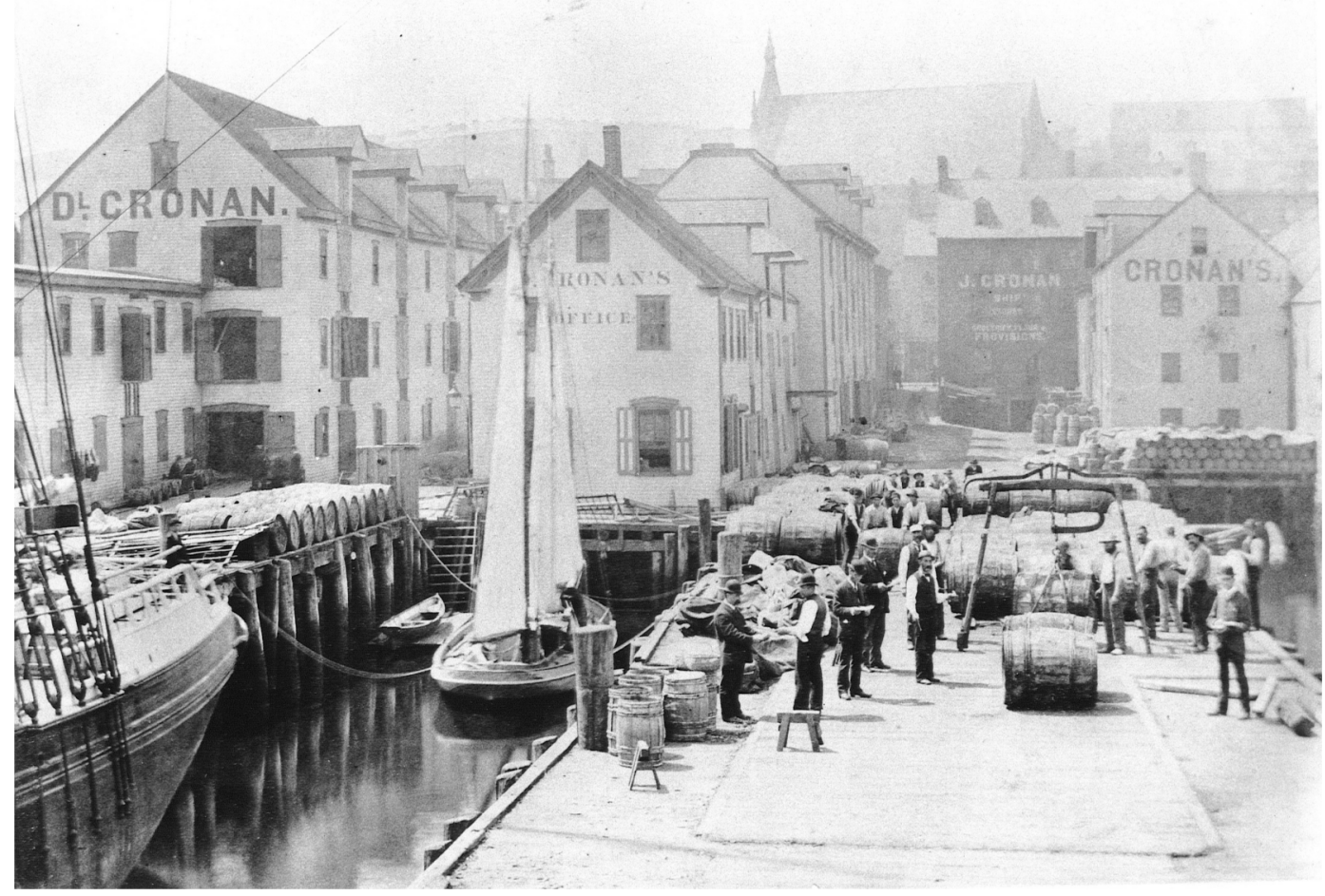

Illustration 3: A typical nineteenth century merchant establishment in Halifax (Cronan's Wharf, probably in 1890s). Maritime Museum of the Atlantic MP107.1.38, reproduced with permission.

He bided his time by selling in Demerara- a market he knew well and where his vessels, when they were not employed in freighting consignments for other merchants, regularly called throughout the years 1837-1840. It was Roche's view that "rum from Demerara will pay better than either sugar or molasses from a foreign island." ${ }^{66}$ In July 1837 he sent there his newly-purchased brig Kate, ${ }^{67}$ a coppered vessel, with orders to her

65 Roche to Samuel P. Musson, at Barbados, 1 November 1838, ibid.

66 Roche to Lewis Jacobs, 18 June 1840, ibid.

67 Registered at 140 tons, "old measure." 
captain to sell quickly and return, if necessary, in ballast. His novice supercargo was given detailed instructions about how to conduct himself once there. He was "to go aboard all the NS vessels in the harbour and at the wharfs, getting from the supercargoes or masters as correct information as possible of the prices at which they have sold, and if possible see their agreement with the merchant...It will then be proper to call on all the merchants who purchase cargoes similar to yours, and furnish each with a bit of your cargo...After receiving all their offers, you can make your calculations which is the best, and decide to sell or not...I cannot impress on you the importance of getting your offers the first day if possible, as the signal for another vessel coming in will induce them to delay as long as possible." 68

Despite this, Demerara was not a success for the supercargo. Roche later chastised the poor man, who had fallen ill in Demerara, for selling at prices "provokingly low." 69 Kate was sent once more to Demerara in 1837 . Her cargo was worth $£ 456$, with the usual mix of codfish, haddock, pork, salmon, butter, and wood products. Then she was chartered to Hamburg. ${ }^{70}$

Kate returned to Demerara in June 1838 with a cargo, worth $£ 605$, to be sold in Demerara. It consisted of cornmeal, pork, and 76,000 feet of white pine lumber, boxes of raisins, and the 3,000 bricks bought in Hamburg. ${ }^{71}$ The captain was told to load ballast then and sail for Puerto Rico. With doubloons from Demerara, he could afford Puerto Rican sugar "unless molasses can be got at a very low rate."72 Whatever was decided, he should sail for the "island where the produce is the most abundant, and therefore with the lowest prices." ${ }^{.73}$ As it turned out, Kate arrived at Puerto Rico too late for the sugar, except "of a very inferior quality at a high price," $" 74$ returning instead with rum, which caused Roche to estimate about $£ 300$ less income. Some of the rum he disposed of in Newfoundland. ${ }^{75}$ Worse still, some of the St. Croix rum was stored in barrels with weak staves and several

Roche to George Mitchell, 13 July 1837, ibid.

69 Roche to Mitchell, 4 January 1838, ibid. Kate returned to Halifax only on 4 June, Mitchell having found freight from Hamburg to London.

70 Roche to How, 5 November 1837, ibid. He informed How that, at Hamburg, sterling was the currency used. He was to return home with a cargo of 3,000 bricks "unless pork can be obtained at a price that will pay well," and 100 barrels of superfine flour, 300 bags of bread, six pipes of gin, twenty barrels of oatmeal and barley, forty cases of gin, wheat as well as thirty quarters (280 bushels) of rye.

71 Roche to Hore, 18 June 1838 , ibid.

72 Roche to Twining, 19 June 1838, ibid.

73 Roche to Twining, 24 June 1838, ibid. If he found himself at St. Thomas he was ordered not to anchor near any "suspicious looking vessels such....as a Guineaman, nor to let your sailors have communication with the sailors and officers of such vessels, and you will require secrecy and caution in the management of your own business on shore that the agents of such vessels get no information that you are worth plundering."

74 Roche to Crane and McGrath of Saint John, 3 October 1838, ibid.

75 Roche to Winter and Preston at Demerara, 28 October 1838, ibid. 
were "crushed and nearly empty when landed."76 It was another sharp disappointment.

His only novelty, begun in 1838 , was to begin to ship to Jamaica. It proved to be his worst recorded mistake when he sent Kate in November 1838 to Montego Bay, Jamaica, with a cargo of alewives, lumber, and staves, worth $£ 596$. Roche did not anticipate any profit from the voyage, "but having the cargo on hand, wish to send it out of the way," in the hope that, by the time the vessel returned, there would be a better market in Demerara for northern exports. ${ }^{77}$ Roche wanted her back early in January for a voyage either to Cuba or to Puerto Rico. The lumber was "St Andrews of very good quality. The staves are the best we can get here." 78 As Roche had ordered two new vessels to be delivered in the spring of 1839 , Kate was to be offered for sale at $\$ 4,500$. Only in March did the vessel return to Halifax, and then with neither letters nor accounts from the merchant who had transacted his Jamaican sales.

When asked for an explanation, the captain had responded: "Messrs. Dewars damned the vessel, the owner and myself. Wished they had never seen her, and asked who they could look to for any expenses incurred for a person they did not know." All this Roche quoted in his letter of apology to Montego Bay, which greatly regretted that "such a character as Mr. Turner was recommended to me as master...Had I imagined such a circumstance as the Kate remaining at Montego Bay without selling her cargo, I should have received and forwarded an introduction from Mr. Almon or some other gentleman here known to you, which would have perhaps prevented the expressions with regard to myself (if used), for I doubt the master's statement." ${ }^{, 79}$ Roche paid dearly for his blunder, eventually receiving a mere $£ 59$ for his produce, the commissions and charges paid exceeding "anything of the kind I have seen from the British West Indies." Owing to this "unfortunate disaster" his losses were even greater than he had anticipated. Nevertheless he dispatched Kate again in June 1839 to Falmouth, Jamaica. He shipped part of her return cargo to Saint John.

By this time Roche had again run down his capital and was forced to revert to freighting other merchants' stock. In October 1839 Kate sailed in October to Montego Bay, with a cargo chartered by Messrs. D. and E. Starr. Her master was ordered to look for freight from Jamaica for New York City, for not less than $\$ 800$. Whatever he received was to be invested in pork and flour. Kate's next voyage for Falmouth, in January 1840, carried freight chartered by Mather Byles Almon. The master was told either to seek freight for

76 Roche to J.T. Peniston and Co., at St. Thomas, 1 November 1838, ibid. Peniston had shipped twenty cases of cherry brandy via Kate which sold for $\$ 10.25$ the case at sixty days' sight, and Roche remarked that "An ingenious cordial manufacturer here imitates the article so well and sells at such a low price that he has spoiled the market for that which has to pay foreign duty."

77 Roach to Winter and Preston at Demerara, 28 October 1838, ibid.

78 Roche to Turner, 4 November 1838, ibid. Turner was told to sell the herrings before the alewives "being fatter fish than alewives they spoil much sooner in warm weather." The brig did not require much ballast, "45 tons with your chains and water in the hold." Roche to William and Robert Dewar, of Montego Bay, 13 March 1839, ibid. 
Halifax or to go in ballast to Cuba for sugar. ${ }^{80}$ In May 1840 the vessel was chartered jointly by George P. Lawson and Levi H. Jacobs, at the rate of $£ 133$ a month, to proceed to Barbados and Demerara with 800 quintals of cod. In August 1840, with Philip Creighton as supercargo, Kate was chartered by W.B. Hamilton for the West Indies with fish, which Roche noted as she departed already smelled high when she was being loaded. ${ }^{81}$

A new vessel, the brig $C W E R{ }^{82}$ ordered in 1836 but whose delivery had been delayed a year, came into service in January 1840 . On her first voyage the master was to sell his cargo in Barbados and take in ballast for Cuba. As she was a new vessel all the spars were to be painted white when she reached a warm climate. CWER carried a cargo on the joint account of Roche and S. Binney, and valued at $£ 1,284$. It was an unhappy voyage, as the brig had been severely knocked about on her first passage, and had to undergo extensive repairs at St. Thomas. This caused Roche to describe it as the "most unprofitable and unfortunate voyage. ${ }^{.83}$

Throughout 1840 CWER, like Kate, was used exclusively for charter. In June CWER under charter by G.C. Whidden sailed for Barbados. She was then sent in ballast to Puerto Rico for a return cargo, calling in at St. Thomas on her homeward passage. Roche wanted rum, as Halifax was severely overstocked with West Indies products. Sales were slow and prices very weak. In October 1840 CWER was chartered by J.L. Starr for Savannah la Mar, Jamaica, under Hezekiah Frith as master. ${ }^{84}$

By January 1841 Roche appeared ready to try his fortune again by speculating alone. This approach may have been forced on him by his inability to find charters for his two vessels. He sent $C W E R$ to Demerara for rum in exchange for a cargo, worth $£ 1,085$, of fish "of an excellent quality," packed in boxes "three years' seasoned," and pork "fresh and good." ${ }^{85}$ Despite the excellence of the goods shipped, returns remained poor. By April 1841 Roche reported discouragingly to Barbados: "Our market is very heavily supplied with

80 Roche to William Hodge, 31 January 1840, ibid. He encouraged the master to maintain a clean ship, as a "dirty vessel is a disgusting sight to an uninterested person, but to one who has a deep interest in her and feels in many other ways than that of merely seeing the object, the effect of the carelessness or the want of industry which has brought her to or allowed her to remain in such a state is particularly mortifying."

81 Roche to Hodge, 24 August 1840, ibid.

82 The name represented his initial and those of his siblings: Charles, William, and Elizabeth. The vessel displaced 120 tons old measure. Ordered in March 1836 to be ready by 6 May 1839, she was built at Sheet Harbour, with Roche furnishing the rigging, blocks, and three lower sails.

83 Roche to James Norwood, 17 June 1840, ibid.

84 Roche to Frith, 12 October 1840, ibid., where he provided details of the vessel. "The whole deck is varnished. I have an utter aversion to so many colours about the top and decks of a vessel. You will please not make use of any green paint about the vessel. Black over the present white streak with the exception of the upper edge...the thickness of the covering board and no more. The top of the trunk all one colour, dark lead."

85 Roche to Frith, January 1841, ibid. He was to sell the long boat at Demerara for between $\$ 80$ and $\$ 100$. 
molasses, a moderate supply of sugar rum not much in market. Scarcely any will be used here soon. The Catholic priests are organizing temperance societies, which the greater part of the labourers are joining and many of the soldiers. ${ }^{86} \mathrm{I}$ am at a loss to know what we shall do with the rum, ordered before the extensive Catholic operation commenced." ${ }^{.87}$ What a change this was from 1836 when he had contentedly reported for the last time: "The Newfoundland, New Brunswick and N. Scotia [rum] consumption being much greater than heretofore, prices have kept up well and are likely to continue good all winter." ${ }^{88}$

Discouraging views springing from the depression that was beginning to grip the entire Atlantic world were shared by at least one other merchant. "With regard to the West India produce," John Zwicker wrote from Lunenburg in 1841 to London, "the export from this place has these last two or three years past been a mere nothing. Our vessels seldom bringing any more than enough for our own consumption." ${ }^{89}$ His explanation for events lay in the collapse of sugar production "at the British islands where our vessels principally trade." Later he more fully explained: "The West India business has for the last few months been attended with so much loss, as almost totally to break up the trade for a time. Lumber could really be bought as low there as here, and fish at Barbados at a lower rate. Folks are now speculating on the anticipated change for the better, whether real or imaginary is difficult to decide. Prospects are certainly not promising. Our little port depends mainly on its prosperity by success in the West India trade, and we have often to exclaim, 'Oh, how absurd for England to give freedom to slavery, so materially has it affected this Province..." ${ }^{\circ 0}$ It was perhaps a thought widely shared by the Halifax mercantile community engaged in Caribbean commerce.

None of this slowed Roche. Between May 1841 and January 1844, when the evidence ends, he sent $C W E R$ on at least another six voyages, carrying cargoes worth on average £914. Barbados ${ }^{91}$ was the usual destination. It was a gamble for Halifax wholesale prices for rum, sugar, and molasses slipped seriously between 1841 and 1844 from the modest peak in 1836-39.

\section{Conclusion}

Between the end of the American War of Independence and Confederation, a major shift occurred in the Atlantic economy, which had a powerful effect upon Nova Scotia.

86 In 1839 Roche reported: "The garrison being deficient of two regiments since autumn has caused a sensible decline in the consumption of liquors this winter. But we shall no doubt soon have reinforcements to make up the usual complement," Roche to J.F. Poinster, St. Thomas, 19 February 1839, ibid.

87 Roche to Winter and Preston, 10 April 1841, ibid.

88 Roche and Kinnear to Hill \& Musson, 22 October 1836, ibid.

89 John Zwicker to William Jackson, Liverpool, England, 17 December 1841, NSA, MG3/4756, 4.

90 John Zwicker to Messrs. Ratchford, Saint John, 17 January 1841, NSA, MG3/4756, 30.

91 Frith was master in May 1841 and Roche candidly informed Samuel Musson, his agent in Barbados: "I do not consider Capt. Frith much acquainted with the system of selling and buying. In sort he is not at all a business man." Enclosed in Roche to Frith, 8 May 1841, NSA, MG3/207. 
Instead of being principally a consumer of colonial products, the industrializing nations, led by Great Britain, increasingly became exporters of machine-made commodities. At the same time there was an enormous shift in the demand for goods produced in the colonies. Spices, sugar products, and wood products declined in importance, to be replaced by rising demand for raw materials of industrial cotton, iron, vegetable oils, petroleum, jute, dyestuffs, and foodstuffs such as wheat, tea, coffee, cocoa, meat, and butter. That is why the end of slavery ultimately mattered very little to Britain's rapidly industrializing economy, which in the 1830s and 1840s expanded at a pace it has never achieved since. The resulting expansion in national wealth, however badly distributed, left the British well-placed to satisfy their needs for sugar and other tropical goods by importing from and exporting to slave plantations in foreign territories, whose cane-crushing mills and slave ships they manufactured and whose production they helped to finance.

By contrast, Nova Scotia was poorly placed to profit from this shift. It exported only limited quantities of the products wanted by those very nations whose wealth, as a result of new demands, was rising the most rapidly. The economic shift meant the relative long-term decline of mercantile-generated wealth, which was replaced by industrial wealth. Just as Nova Scotia's capitalists were beginning to accumulate considerable private wealth, the economic ground was shifting. With it was imposed a serious limit on the potential in Nova Scotia for further substantial wealth expansion. First hit were men such as Roche, despite their vast experience of both the Caribbean and the North American markets and their well-connected links to small pools of capital in Nova Scotia itself. Even with their efficient little vessels in the Atlantic, produced at the lowest cost per ton, manned by willing and able sailors and captained by young, yet skilled Nova Scotians, there was less and less money to be found in the West Indies carrying trade by the end of the 1830s. It was a market that mattered less and less both to the overall Atlantic economy and to the local economy of Nova Scotia itself.

Roche lived through the last decades of the heyday. In the 1840s the British antislavery Squadron, by forcing up slave prices in the Americas, helped render Puerto Rican sugar no longer competitive with Cuban. Then in the 1850s the fall in sugar prices knocked Cuba out of the trade. The capacity of the sugar areas to absorb northern products stagnated with the breakup of slavery, beginning in the 1830s, while demand for Caribbean products in British North America grew only slowly, or, as far as rum was concerned, fell absolutely, under the twin challenges of import substitution in the Canadas and the temperance movement in the Maritimes.

Roche was not inflexible. He saw the problem and understood it as early as anyone who kept a house on Water Street. Like others, he had no solution. "Some great change must soon take place in the governments and trade of the British West Indies and American colonies," he wrote in 1841.

At present the trade is injurious and unprofitable to both. Slaves are emancipated in the British colonies, and at the same time a premium is given to slave holders in the foreign colonies by selling N. American and U.S. manufactures and productions to the BW Indians at rates increased considerably by their own duties. The amount taken from them in specie and transferred to foreign agriculture in exchange for articles 
which he is enabled to sell us at a much lower rate than it is possible for the British colonies to produce there by free labour. In this way the money will be drained away from our colonies to encourage that very system, to abolish which the British people have made most generous expenditure of their own money and sacrificed the property of the WI colonies. ${ }^{92}$

If Roche persisted longer in the West Indies trade than many, when he left it he was not a broken man. He thrived as president of the Union Marine Insurance Company of Halifax, a business with which, as a ship owner with remarkable good luck, he was intimately familiar. ${ }^{93}$

Were West Indies products the engine of economic growth in Nova Scotia, or merely the preoccupation of many of the wealthiest merchants? Between 1832 and 1853, Nova Scotia annually imported about 10.6 million pounds of sugar, 740,000 gallons of molasses and 340,000 gallons of rum. Had these products been entirely consumed in Nova Scotia, it would have seemed a poor bargain for the consumer, whatever profits the merchants could make and accumulate for effecting the exchange. Consider all the difficulties in catching, curing, making and shipping fish and fish oil; all the labour in cutting, hauling and milling lumber into boards and staves, building vessels; importing rigging and sailcloth and overseeing their upkeep; raising livestock, barreling beef, pork and butter; drawing up agreements and contracts; maintaining proper books; paying attorneys to oversee the almost inevitable lawsuits; and financing enterprises - merely to acquire a lot of tooth-decaying, health-undermining sugar in various forms. Economists call it comparative advantage.

The trouble for Nova Scotians who produced for the export market in these ways was that their obvious market for fish and lumber, in the United States, remained largely closed to them. Though markets were found in Great Britain and Ireland for Nova Scotia's lumber and timber, the United Kingdom could supply itself with fish. By contrast the sugar colonies, so long as they were willing to consume North American fish and oil and needed northern wood products, would remain Nova Scotia's best customers. It was a market serviceable by inexpensively and locally-built small vessels, most under 120 measured tons, which could carry a cargo-from the 1820 s through the 1840 s - worth less than $\mathrm{H} £ 400-\mathrm{H} £ 1,000$ and be occasionally, if not regularly, profitable. The market was not exclusively theirs to service. Newfoundland was a major rival in fish supply and New Brunswick in wood products. Yet it was the United States and from the 1820s, the new Spanish American republics, that posed a greater commercial threat. They entered the British West Indies market principally because the British North American colonies together could not supply their needs. These requirements included livestock, supplied largely from Spanish America, and manufactured goods, largely from Britain and the United States, as well as flour, bread, biscuit, bacon and ham, beef and pork, cheese and butter, cornmeal, oatmeal, rice, wheat, and other grains.

92 To Samuel P. Musson, Barbados, 8 May 1841, ibid.

93 For his will, inventory, and estate papers see NA, \#3658 reel 22521. His net worth amounted $\$ 104,685$ in mortgages, notes of hand, bank accounts, insurance and other companies, land and cash. In 2013 values his estate would amount to not less than $\$ 2.5$ million. 
The commercial aim of Nova Scotia's merchants was never to carve a substantial niche for itself to supply such needs. Rather it was to remain the predominant British North American supplier of northern commodities to the West Indies and the principal distributor to other British North American colonies of West Indies imports, especially rum, sugar, and molasses. At all times after 1783 it took the lion's share of such imports, consumed some of them, and re-exported the rest to New Brunswick, Newfoundland, Prince Edward Island, and Quebec. This business enabled merchants, chiefly those in Halifax, to purchase, for instance, all the fish they needed to supply their markets in the Caribbean. Some of the earnings in this trade enabled Nova Scotia to meet part of the cost of the variety of finished and semi-finished goods that it imported from the United Kingdom and the United States. Chief among these were textiles, clothing of all sorts, cordage and tackle, dry goods, crockery, furniture, glassware, gunpowder, wrought and unwrought iron and other ferrous and non-ferrous metals, and metal products, sails and sailcloth, soap, stationery, tea, and wine.

In 1826 the Acadian Recorder, frequently an acute observer of the passing economic scene, believed that beyond the West Indies trade, Nova Scotia lacked another "external commerce by which we can derive any profit, and which at the same time gives employment to any large portion of commercial capital or enterprise." "'It reminded its readers:

The fish, lumber \&c., which we send hither form the bulk of our export trade. For those articles of home production, we receive in return either bills, specie or West Indies produce, and from this source we have constantly derived nearly all our means of paying for the articles of English and East India manufacture, which are either necessary for our own consumption or conducive to our comfort. It is trade that employs an immense number of industrious men directly and indirectly. On its success has Halifax in great measure depended for her existence, and the agricultural parts of the Province their imports and circulating medium. The revenues arising from this branch of business are also the principal fund out of which we have been enabled to undertake and complete many public works of great usefulness and even of relative grandeur, besides its chief means of supporting the civil list, chargeable on the province. This profitable commerce has hitherto given subsistence to our fishermen. It has supplied the merchant with a mode of employing his capital and skill to advantage, and has diffused through every channel of business a life and vigour which could not have existed without its aid.

The generation that followed experienced almost complete disillusionment. Even as Nova Scotia's trade with the West Indies diversified from almost total reliance on the British islands to dependence on the foreign islands and Brazil, the trade began to stagnate. Dynamic growth in trade came instead from commercial ties with the United States. As the aggregate value of imports from the West Indies fell in the 1830s, exports rose. Yet when we combine the value of imports and exports, we see that their overall value rose only marginally. From being the most valuable trade route in the early 1830s and before, it fell into third place behind the United States and the United Kingdom. This pattern continued for the rest of the century and beyond. 